\title{
PHENOLIC COMPOUNDS FROM INDONESIAN WHITE TURMERIC (CURCUMA ZEDOARIA) RHIZOMES
}

\section{DYAH UTAMI CAHYANING RAHAYU ${ }^{1 *}$, DWI AYU SETYANI ${ }^{1}$, HANHAN DIANHAR ${ }^{2}$, PURWANTININGSIH SUGITA ${ }^{3}$}

${ }^{1}$ Department of Chemistry, Faculty of Mathematics and Natural Sciences, Universitas Indonesia, Depok 16424, Indonesia. ${ }^{2}$ Chemistry Study Program, Faculty of Mathematics and Natural Sciences, Universitas Negeri Jakarta, Jakarta 13220, Indonesia. ${ }^{3}$ Department of Chemistry, Faculty of Mathematics and Natural Sciences, Institut Pertanian Bogor, Dramaga Bogor 16680, Indonesia. Email: dyahutamicr@sci.ui.ac.id

Received: 11 May 2020, Revised and Accepted: 22 June 2020

ABSTRACT

Objective: The aim of the present study is to isolate phenolic compounds from Curcuma zedoaria rhizomes grown in Bogor, West Java, Indonesia, which will enrich phytochemical information from this plant.

Methods: C. zedoaria rhizomes were macerated in methanol then followed by increasing polarity partitions with $n$-hexane, ethyl acetate (EtOAc), and methanol, respectively. EtOAc fraction was further fractionated using various chromatography techniques to yield two isolated fractions, $\mathrm{Z1}$ and $\mathrm{Z} 2$. These two isolated fractions were then characterized to determine their compound structures.

Results: Fourier Transform-InfraRed (FTIR), Ultraviolet-Visible (UV-Vis), and Liquid Chromatography Mass Spectrometry tandem Mass Spectrometry LC-MS/MS spectral data, Z1 fraction was elucidated as curcuminoid derivative, that is, dimethoxycurcumin (DiMC, 1), while Z2 fraction was yielded as a mixture consisted of flavonoid and coumarin derivatives, 3,5,7-trihydroxy-4'-methoxyflavone (kaempferide, 2) and 7-methoxy coumarin (herniarin, 3).

Conclusion: This study reveals useful information regarding phenolic constituents of Indonesian $C$. zedoaria rhizomes. Further research needs to be carried out to purify other compounds contained and to conduct bioactivity assays.

Keywords: Curcuma zedoaria, Dimethoxycurcumin (DiMC, 1), Phenolic, 7-Methoxy coumarin (herniarin, 3), 3,5,7-Trihydroxy-4'-methoxyflavone (kaempferide, 2), White turmeric.

(C) 2020 The Authors. Published by Innovare Academic Sciences Pvt Ltd. This is an open access article under the CC BY license (http://creativecommons. org/licenses/by/4. 0/) DOI: http://dx.doi.org/10.22159/ajpcr.2020.v13i7.38249

\section{INTRODUCTION}

In recent years, natural products derived from terrestrial plants, animals, microorganisms, and marine organisms play an important role in traditional medicines [1]. Curcuma zedoaria, also known as temu putih, white turmeric, zedoaria, or gajutsu, is belonging to Zingiberaceae family and close relative to Curcuma longa. This plant has dark orange-fleshed tubers similar to C. longa. This plant is indigenous to Bangladesh, Sri Lanka, India and is also widely cultivated in China, Japan, Brazil, Nepal, and Thailand [2]. Its rhizomes are commonly consumed traditionally as medicine in Asia for curing stomach diseases, toothache, blood stagnation, leucoderma, tuberculosis, enlargement of spleen, and for promoting menstruation, while the roots are usually used in the treatment of flatulence, dyspepsia, cold, cough, fever, and infections [3]. Phytochemical investigation of this plant showed that $C$. zedoaria is a rich source of essential oils, terpenoids, and curcuminoids $[4,5]$. C. zedoaria was also reported to have wide range of pharmacological activities such as antimicrobial and antifungal, anti-amoebic, larvicidal effect, antinociceptive, analgesic, antiallergic, antiulcer, anti-inflammatory, hemagglutinating, antimutagenic, anticancer, and hepatoprotective $[5,6]$.

Having predominant of terpenoids, C. zedoaria rhizomes capture scholars' attention to investigate novel terpenoids or essential oils from this plant. Two diterpenes, curcuzedoalide and curcuminol D, were obtained from C. zedoaria cultivated in South Korea [7]. Curdione and curcumol belonging to sesquiterpenes had been isolated previously from essential oils of Chinese $C$. zedoaria rhizomes [8]. From methanol extract of $C$. zedoaria rhizomes, purchased from Kyoungdong Herbal Market in Seoul, five sesquiterpenes had been reported such as isoprocurcumenol, germacrone, curzerenone, curcumenol, and curcuzedoalide [9]. Moreover, since known as terpenoids-rich plant, this plant, together with other species Curcuma, had been profiled for distinguishing Indian Curcuma species based on its non-polar terpenes contains [10]. Nevertheless, there are still limited studies on phenolic compounds contained from $C$. zedoaria rhizomes. Align with our interest in a phytochemical investigation of Indonesian Curcuma [11-17], in the present study, we conduct phenolic isolation and characterization from methanol crude extract of $C$. zedoaria rhizomes grown in West Java, Indonesia.

\section{METHODS}

Chemicals and instrument

Fractions were monitored using thin-layer chromatography (TLC) and performed on precoated $0.25 \mathrm{~mm}$ thickness of silica gel $60 \mathrm{GF}_{254}$ plates (Merck). TLC spots were visualized under ultraviolet (UV) light (254 and $366 \mathrm{~nm}$ ) and stained using $\mathrm{Ce}\left(\mathrm{SO}_{4}\right)_{2} \cdot 4 \mathrm{H}_{2} \mathrm{O} 1.5 \%$ in $\mathrm{H}_{2} \mathrm{SO}_{4} 2 \mathrm{~N}$. Moreover, all silica gel for various chromatography techniques were also purchased from Merck, such as, Si 60 G (column pack) and Si 60 0.2-0.5 $\mathrm{mm}$ (sample adsorbed) from vacuum liquid chromatography (VLC), $\mathrm{Si}$ $60(0.063-0.200 \mathrm{~mm})$ for column chromatography (CC), and Si $60 \mathrm{PF}_{2}$ containing gypsum for radial chromatography (RC) and preparative-TLC (p-TLC). The isolated fractions were elucidate using Fourier TransformInfraRed (FTIR) Shimadzu IR Prestige 21, Ultraviolet-Visible (UV-Vis) Shimadzu UV-2450, and Liquid Chromatography Mass Spectrometry tandem Mass Scpectrometry (LC-MS/MS) with LC system ACQUITY UPLC ${ }^{\circledR} \mathrm{H}$-Class System (Waters, USA) and MS Xevo G2-S QTof (Waters, USA). LC-MS/MS with MS detection at $50 \mathrm{eV}$ was performed under the following conditions: Column: C18 (1.8 $\mu \mathrm{m} 2.1 \mathrm{~mm} \times 100 \mathrm{~mm}) \mathrm{HSS}$, temperature: $50^{\circ} \mathrm{C}$ (column) and $25^{\circ} \mathrm{C}$ (room), mobile phase: Water +5 $\mathrm{mM}$ ammonium formic and acetonitrile $+0.05 \%$ formic acid, flow rate: $0.2 \mathrm{~mL} / \mathrm{min}$ (gradient-step) running $23 \mathrm{~min}$, and injection volume: 5 $\mu \mathrm{L}$ with MS system of ES (electrospray ionization) in ion positive mode 
and de-solvation temperature of $350^{\circ} \mathrm{C}$. Chemicals used for isolation were in both technical (CV. Satya Darmawan) and pro analysis (Merck) grades, such as, methanol $(\mathrm{MeOH}), n$-hexane, ethyl acetate (EtOAc), dichloromethane (DCM), chloroform $\left(\mathrm{CHCl}_{3}\right)$, and acetone.

\section{Collection of plant material}

C. zedoaria, Rosc. rhizomes were collected and identified from Biopharmaca Research Centre, Institut Pertanian Bogor, West Java, Indonesia.

\section{Isolation of phenolic compounds from $C$. zedoaria rhizomes}

Fresh-harvested C. zedoaria rhizomes were washed, sliced into small pieces, dried, and ground into a fine powder using a powdering mill. The air-dried powdered rhizomes $(2.0 \mathrm{~kg})$ were then extracted 3 times with $\mathrm{MeOH}$ at room temperature. $\mathrm{MeOH}$ crude extract (65 g) was then partitioned with increasing polarity using $n$-hexane, EtOAc, and $\mathrm{MeOH}$, respectively, afforded $7.17 \mathrm{~g} n$-hexane, $30.59 \mathrm{~g}$ EtOAc, and $4.31 \mathrm{~g} \mathrm{MeOH}$ extracts.

EtOAc extract (20 g) was further fractionated using VLC with gradient solvent of $n$-hexane:EtOAc $(9: 1$ to $5: 5, \mathrm{v} / \mathrm{v}), \mathrm{EtOAc}$, and $\mathrm{MeOH}$, respectively, to obtain four fractions (A1-A4). A1 fraction (700 mg) was loaded on a silica gel CC and eluted with $n$-hexane:EtOAc $(9: 1, \mathrm{v} / \mathrm{v})$ to afford four fractions (B1-B4). B2 fraction then was further fractionated using RC with gradient solvent of $n$-hexane:EtOAc $(17: 3, \mathrm{v} / \mathrm{v})$ to yield two fractions (C1-C2). Furthermore, A2 fraction (1.0 g) was eluted with gradient solvent of $n$-hexane:EtOAc $(17: 3, \mathrm{v} / \mathrm{v})$ in CC to obtain 16 fractions (D1-D16) while A4 fraction (1.0 g) was fractionated under the similar condition with A2 fraction to yield three fractions (E1-E3). Fractions D1 and E1 showed similar $\mathrm{R}_{f}$ with $\mathrm{C} 1$ fraction; therefore, these fractions were mixed and further purified using p-TLC ( $n$-hexane: $\mathrm{CHCl}_{3} 2: 8, \mathrm{v} / \mathrm{v}$ ) afforded Z1 fraction $(10.2 \mathrm{mg}$ ). E3 fraction then was further purified with p-TLC ( $n$-hexane: $\mathrm{CHCl}_{3} 2: 8, \mathrm{v} / \mathrm{v}$ ) to afford Z2 fraction (14.4 mg). Both Z1 and Z2 fractions were subjected to characterize using FTIR, UV-Vis, and LC-MS/MS. According to spectroscopic data, Z1 fraction was identified as dimethoxycurcumin (DiMC, 1), while Z2 fraction was recognized as a mixture consisted of 3,5,7-trihydroxy-4'-methoxyflavone (kaempferide, 2) and 7-methoxy coumarin (herniarin, 3 ).

\section{Characterization data}

Z1 fraction dimethoxycurcumin (DiMC, 1); yellow to orange solid; TLC spot $\mathrm{R}_{f} 0.25$ ( $n$-hexane: $\left.\mathrm{CHCl}_{3} 3: 7, \mathrm{v} / \mathrm{v}\right), 0.6$ ( $n$-hexane:EtOAc 8:2, v/v), and 0.92 (DCM:MeOH 19:1, v/v); FTIR (KBr) v $\left(\mathrm{cm}^{-1}\right): 3598-3394(\mathrm{O}-\mathrm{H})$, 2955 (C-H $s p^{2}$ ), 2928-2860 (C-H sp $\left.p^{3}\right), 1733$ (C=0), 1604 (C=C alkene), 1510 ( $\mathrm{C}=\mathrm{C}$ aromatic), and 1267 (C-O-C ether); UV-Vis $(\mathrm{MeOH}) \lambda_{\text {max }}(\mathrm{nm})$ : 263 (benzoyl chromophore) and 402 (curcuminoid chromophore), no shift wavelength observed in addition of shift reagents; and LC-MS/MS:
LC rt $12.77 \mathrm{~min}, \mathrm{MS}(70 \mathrm{eV}, \mathrm{m} / \mathrm{z}): 397.157[\mathrm{M}+\mathrm{H}]^{+}, 366.138,335.167$, 249.260, 205.085, 199.134 (base peak), 163.075, and 149.024

Z2 fraction mixture of 3,5,7-trihydroxy-4'-methoxyflavone (kaempferide, 2) and 7-methoxy coumarin (herniarin, 3); lightyellowish oil; FTIR $(\mathrm{KBr}) \cup\left(\mathrm{cm}^{-1}\right): 3314-3176(\mathrm{O}-\mathrm{H}), 2959\left(\mathrm{C}-\mathrm{H} s p^{2}\right)$, 2927-2857 (C-H sp3), 1750 (C=0), $1616(\mathrm{C}=\mathrm{C}), 1550$ (aromatic C=C), and 1262 (C-O-C ether); UV-Vis $(\mathrm{MeOH}) \lambda_{\max }(\mathrm{nm}): 215,275$ (benzoyl chromophore), and 323 (cinnamoyl chromophore), addition of shift reagents see Table 1; and LC-MS/MS: LC rt 9.35 min (kaempferide, 2), MS (70 eV, m/z): $301.061[\mathrm{M}+\mathrm{H}]^{+}, 287.126,285.080,229.123$ (base peak), 201.128, 121.102, 105.071, and 91.055, while LC rt $6.77 \mathrm{~min}$ (herniarin, 3), MS (70 eV, m/z): $177.055[\mathrm{M}+\mathrm{H}]^{+}$(base peak), 148.052, $135.020,121.065,116.986,103.055,91.055$, and 77.039.

\section{RESULTS AND DISCUSSION}

C. zedoaria, belonging to Zingiberaceae family, was selected for the presentstudy by recent literature showed that this species is usually used as traditional medicine and recognized to be a rich source of terpenoids $[18,19]$. However, relatively little was explored regarding extraction and separation processes of phenolic compounds from C. zedoaria rhizomes. Phenolics investigation of $\mathrm{MeOH}$ crude extract of $C$. zedoaria rhizomes using successive various chromatography techniques resulted in the isolation and characterization of two fractions, that is, Z1 fraction which was identified as dimethoxycurcumin (DiMC, 1) and Z2 fraction which was obtained in a mixture of 3,5,7-trihydroxy- 4'-methoxyflavone (kaempferide, 2) and 7-methoxy coumarin (herniarin, 3). Fig. 1 showed the chemical structures of isolated phenolics from $C$. zedoaria rhizomes which were elucidated using FTIR, UV-Vis, and LC-MS/MS.

FTIR spectra of $\mathbf{1}$ (Z1 fraction) showed characteristic peaks of phenolics at a wavenumber of 3598-3394, 2955, 1510, and $1267 \mathrm{~cm}^{-1}$ indicated $\mathrm{O}-\mathrm{H}, \mathrm{C}-\mathrm{H} s p^{2}, \mathrm{C}=\mathrm{C}$ aromatic, and C-O-C ether, respectively. In addition, this compound also showed peaks for $\mathrm{C}-\mathrm{H} s p^{3}, \mathrm{C}=\mathrm{O}$, and $\mathrm{C}=\mathrm{C}$ alkene at a wavenumber of 2928-2860,1733, and 1604, respectively. Phenolics have an aromatic ring with at least one hydroxyl group [20]. The presence of hydroxyl group $(\mathrm{O}-\mathrm{H})$ in the FTIR spectra of 1 is due to keto-enol tautomerization. Moreover, maximum absorbance in UV-Vis spectra of 1 appeared at the wavelength of 263 and $402 \mathrm{~nm}$. A peak at $263 \mathrm{~nm}$ indicated benzoyl chromophore, while a peak in the visible region $(402 \mathrm{~nm})$ specified as a curcuminoid chromophore proven by the yellow appearance of $\mathbf{1}$ [21]. To support FTIR and UV-Vis analysis, LC-MS/MS characterization of $\mathbf{1}$ was recorded. LC chromatogram resulted from the positive ion method showed one dominant peak at the retention time of $12.77 \mathrm{~min}(75.72 \%)$. MS spectra showed the

Table 1: Wavelength shifting of the mixture of 2 and 3 in various shifting reagents

\begin{tabular}{|c|c|c|c|c|c|}
\hline \multirow[t]{2}{*}{ Reagents } & \multicolumn{2}{|c|}{ Cinnamoyl (nm) } & \multicolumn{2}{|c|}{ Benzoyl (nm) } & \multirow[t]{2}{*}{ Remarks } \\
\hline & Initial & Shift & Initial & Shift & \\
\hline $\mathrm{MeOH}$ & 323 & - & 275 & - & Flavonol \\
\hline $\mathrm{MeOH} / \mathrm{AlCl}_{3}$ & 323 & 0 & 275 & 0 & No $o$-diOH on A and B ring \\
\hline $\mathrm{MeOH} / \mathrm{AlCl}_{3}^{3} / \mathrm{HCl}$ & 383 & +60 & 322 & -1 & 3-OH (with or without $5-\mathrm{OH}$ ) \\
\hline $\mathrm{MeOH} / \mathrm{NaOAc}$ & 323 & 0 & 281 & +6 & $7-\mathrm{OH}$ \\
\hline $\mathrm{MeOH} / \mathrm{NaOAc} / \mathrm{H}_{3} \mathrm{BO}_{3}$ & 323 & 0 & 275 & 0 & No $o$-diOH on A and B ring \\
\hline
\end{tabular}<smiles>COc1ccc(/C=C/C(=O)CC(=O)/C=C/c2ccc(OC)c(OC)c2)cc1OC</smiles>
1<smiles>COc1ccc(-c2cc(=O)c3c(O)cc(O)cc3o2)cc1O</smiles>

2

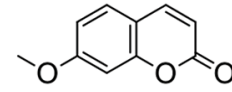

3

Fig. 1: Phenolics from $\mathrm{MeOH}$ crude extract of Curcuma zedoaria rhizomes 
molecular ion of $397.157 \mathrm{~m} / \mathrm{z}[\mathrm{M}+\mathrm{H}]^{+}$which corresponds to $\mathrm{C}_{23} \mathrm{H}_{24} \mathrm{O}$ and fragmented peaks at 366.138, 335.167, 249.260, 205.085, 199.134 (base peak), 163.075, and 149.024 which belongs to the fragmentation scheme of 1 (Fig. 2).

To the best of our knowledge, this is the first report on isolating compound $\mathbf{1}$ from $\mathrm{MeOH}$ crude extract of Indonesian C. zedoaria rhizomes. This compound belonging to curcuminoids was obtained previously from Indian turmeric species (C. longa Linn.) [22,23]. This compound is an analog of curcumin which is commonly known as synthetic curcumin derivative displayed a wide range of bioactivities such as antiproliferative, antioxidant, anti-inflammatory, and anticancer [24-27]. Moreover, curcuminoid derivatives are found to be the major compounds in several turmeric species. Bisdemethoxy curcumin had previously reported from Chinese C. zedoaria rhizomes [28]. Other curcuminoids, such as curcumin, demethoxy curcumin, and bisdemethoxy curcumin had been reported to be isolated from Vietnamese, Indonesian, and Indian C. longa rhizomes [29-31].

A mixture of $\mathbf{2}$ and $\mathbf{3}$ (Z2 fraction) exhibited typical absorption peaks of phenolics, that is, $\mathrm{O}-\mathrm{H}, \mathrm{C}-\mathrm{H} s p^{2}, \mathrm{C}-\mathrm{O}-\mathrm{C}$ ether, and $\mathrm{C}=\mathrm{C}$ aromatic at the wavenumber of 3314-3176, 2959, 1550, and $1262 \mathrm{~cm}^{-1}$, respectively. Besides, this mixture also showed peaks at the wavenumber of 29272857, 1750, and $1616 \mathrm{~cm}^{-1}$ indicated $\mathrm{C}-\mathrm{H} s p^{3}, \mathrm{C}=\mathrm{O}$, and $\mathrm{C}=\mathrm{C}$ alkene, respectively. Furthermore, UV-Vis spectra of the mixture showed the maximum wavelength of 275 and $323 \mathrm{~nm}$ belongs to benzoyl and

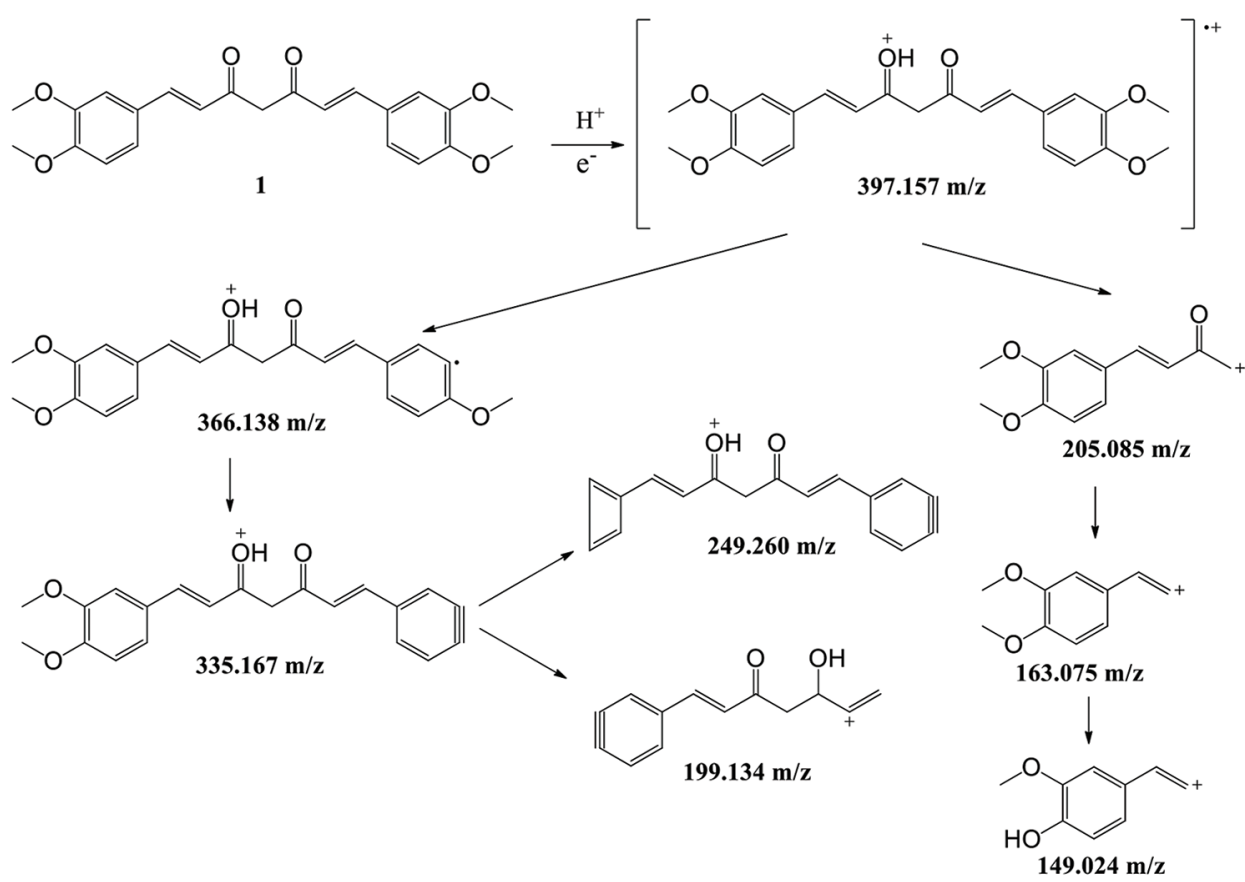

Fig. 2: Fragmentation scheme of 1<smiles>COc1ccc(-c2oc3cc(O)cc(O)c3c(=O)c2O)cc1</smiles>

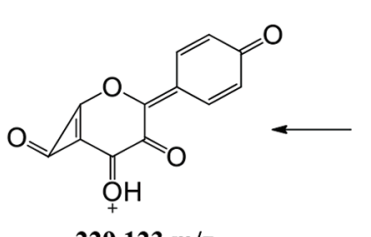<smiles>O=C1C(=O)c2c(O)cc(O)cc2OC1=C1C=CC(O)C=C1</smiles>

$285.080 \mathrm{~m} / \mathrm{z}$

$229.123 \mathrm{~m} / \mathrm{z}$<smiles>CCC</smiles><smiles>O=C1C=CC(=C2OC=CC(=O)C2=O)C=C1</smiles>

$201.128 \mathrm{~m} / \mathrm{z}$

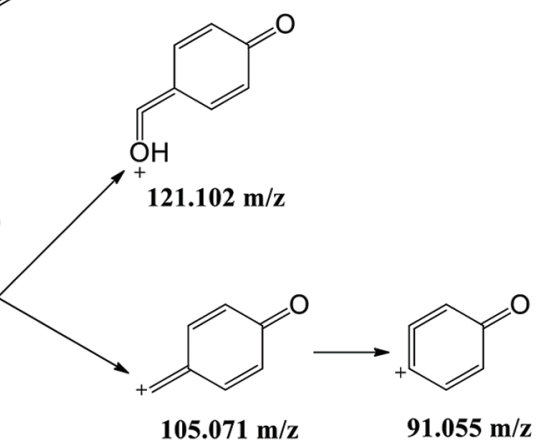

Fig. 3: Fragmentation scheme of 2 


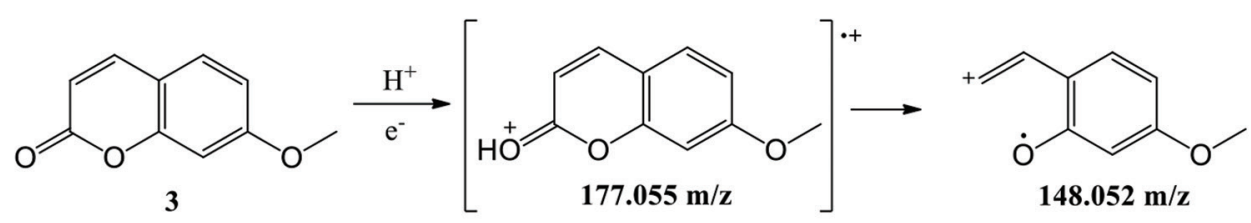<smiles></smiles>

$121.065 \mathrm{~m} / \mathrm{z}$

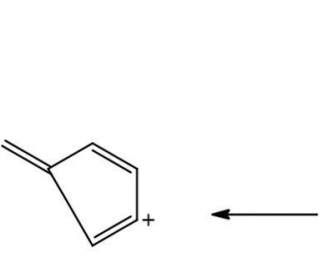

$77.039 \mathrm{~m} / \mathrm{z}$<smiles>C=C1C=CC=CC1=O</smiles>

$103.055 \mathrm{~m} / \mathrm{z}$<smiles>C=Cc1ccccc1OCCCOC(C)C</smiles>

$116.986 \mathrm{~m} / \mathrm{z}$<smiles>[O-]c1ccccc1</smiles>

$91.055 \mathrm{~m} / \mathrm{z}$

Fig. 4: Fragmentation scheme of $\mathbf{3}$

cinnamoyl chromophores, respectively, indicated the characteristic peaks for flavonoid, especially flavonol [32]. Shift reagents were then used to elucidate the substituent in flavonoids [33] and summarized in Table 1.

According to Table 1, the mixture consisted of predominant flavonol having three free hydroxyl groups at positions of C3, C5, and C7. Hydroxyl group, which usually appears at C4' position, appeared as methoxy $\left(-\mathrm{OCH}_{3}\right)$ substituent. Furthermore, there were no $o$-dihydroxyl groups in both ring A and B in flavonol. Since the fraction was still in a mixture proven by the appearance of a $\lambda_{\text {max }}$ of $215 \mathrm{~nm}$, LC-MS/MS was carried out to analyze the minor compound. LC chromatogram of the mixture revealed two peaks at the retention time of 6.77 and $9.35 \mathrm{~min}$ with the average area of $24.29 \%$ and $68.16 \%$, respectively. A peak at 9.35 min was identified as 2 showing the dominant compound in the mixture, while a peak at 6.77 min belonged to 3 based on MS spectra analysis. Compound $\mathbf{3}$ also showed the cinnamoyl chromophore analyzed using UV-vis. Therefore, this peak in UV-Vis appeared in a simultaneous way with a similar chromophore of compound $\mathbf{2}$. Moreover, the coumarin derivative 3 was reported to have a strong absorption peak at 200-250 and 300-350 $\mathrm{nm}$ [34,35]. MS spectra of a peak at 9.35 min exhibited the molecular ion of $301.061[\mathrm{M}+\mathrm{H}]^{+}$which corresponds to $\mathrm{C}_{6} \mathrm{H}_{12} \mathrm{O}_{6}$ and fragmented peaks at 287.126, 285.080, 229.123 (base peak), 201.128, 121.102, 105.071, and 91.055 which belongs to the fragmentation scheme of 2 . Furthermore, MS spectra at 6.77 min of retention time showed the typical MS peak for $3\left(\mathrm{C}_{10} \mathrm{H}_{8} \mathrm{O}_{3}\right)$, revealing the molecular ion of $177.055[\mathrm{M}+\mathrm{H}]^{+}$as base peak and fragmented peaks of 148.052, 135.020, 121.065, 116.986, 103.055, 91.055, and 77.039. Fragmentation scheme of $\mathbf{2}$ and $\mathbf{3}$ are presented in Figs 3 and 4, respectively.

Based on the literature study, this is the first finding of compounds $\mathbf{2}$ and $\mathbf{3}$ from Indonesian $C$. zedoaria rhizomes. Compound $\mathbf{2}$ had been isolated previously from Alpinia galanga (Zingiberaceae), Tecomaria capensis var. aurea (Bignoniaceae), and Tamarix gallica (Tamaricaceae) [36-38]. Furthermore, compound $\mathbf{3}$ had been reported previously from Matricaria chamomilla, Zanthoxylum zanthoxyloides, and Alpinia calcarata (Zingiberaceae) [39-41].

\section{CONCLUSIONS}

From $\mathrm{MeOH}$ crude extract of $C$. zedoaria rhizomes, three phenolic compounds were successfully isolated through various chromatography techniques, and identified as, dimethoxycurcumin (DiMC, 1) and a mixture of 3,5,7-trihydroxy-4'-methoxyflavone (kaempferide, 2) and 7-methoxy coumarin (herniarin, 3). Further research needs to be carried out to purify other compounds contained and to conduct bioactivity assays.

\section{AUTHORS' CONTRIBUTIONS}

Conceptualization, DUCR; formal analysis and data acquisition, DAS, DUCR, HD; investigation, DAS; writing - original draft preparation, DUCR; writing - review and editing, DUCR, HD, PS; supervision, DUCR, HD, PS; project administration, DUCR; funding acquisition, DUCR. All authors have read and agreed to the published version of the manuscript.

\section{CONFLICTS OF INTEREST}

The authors declare no conflicts of interest related to this work. The funders had no role in the design of the study; in the data collection, analyses, or interpretation; in the writing of the manuscript; or in the decision to publish the results.

\section{AUTHORS' FUNDING}

The authors acknowledge Publikasi Terindeks Internasional (PUTI) Prosiding 2020 Research Grant No. NKB-963/UN2.RST/ HKP.05.00/2020 from DRPM Universitas Indonesia for funding this research.

\section{REFERENCES}

1. Yuan H, Ma Q, Ye L, Piao G. The traditional medicine and modern medicine from natural products. Molecules 2016;21:559.

2. Lobo R, Prabhu KS, Shirwaikar A, Shirwaikar A. Curcuma zedoaria Rosc. (White turmeric): A review of its chemical, pharmacological and ethnomedicinal properties. J Pharm Pharmacol 2009;61:13-21.

3. Ji S, Fattahi A, Raffel N, Hoffmann I, Beckmann MW, Dittrich R, et al. Antioxidant effect of aqueous extract of four plants with therapeutic potential on gynecological diseases; Semen persicae, Leonurus cardiaca, Hedyotis diffusa, and Curcuma zedoaria. Eur J Med Res 2017;22:50.

4. Singh P, Singh S, Kapoor IP, Singh G, Isidorov V, Szczepaniak L. Chemical composition and antioxidant activities of essential oil and oleoresins from Curcuma zedoaria rhizomes, part-74. Food Biosci 2013;3:42-8

5. Rajkumari S, Sanatombi K. Nutritional value, phytochemical composition, and biological activities of edible Curcuma species: A review. Int J Food Prop 2017;20 Suppl 3:S2668-87.

6. Dosoky NS, Setzer WN. Chemical composition and biological activities of essential oils of Curcuma species. Nutrients 2018;10:1196.

7. Park GG, Eun SH, Shim SH. Chemical constituents from Curcuma 
zedoaria. Biochem Syst Ecol 2012;40:65-8.

8. Zhang Y, Tan X, Tu X, Ling F, Wang G. Efficacy and antiparasitic mechanism of curdione from Curcuma zedoaria Curcuma zedoaria against Gyrodactylus kobayashii in goldfish. Aquaculture 2020;523:735186

9. Lee TK, Trinh TA, Lee SR, Kim S, So HM, Moon E, et al. Bioactivitybased analysis and chemical characterization of anti-inflammatory compounds from Curcuma zedoaria rhizomes using LPS-stimulated RAW264.7 cells. Bioorg Chem 2019;82:26-32.

10. De B, Karak S, Das S, Begum S, Gupta P, Pradhan ID, et al. Profiling non-polar terpenes of rhizomes for distinguishing some Indian Curcuma species. J Appl Res Med Aromat Plants 2019;13:100207.

11. Rahayu DU, Adilah SN, Sugita P. Antioxidant activity of methanol extract from Indonesian Curcuma heyneana rhizome. Eur J Pharm Med Res 2018;5:582-8.

12. Sugita P, Octaviana N, Wukirsari T, Rahayu DU. Chemical constituent and antioxidant activity of methanol extract from Indonesian Curcuma aeruginosa Roxb. rhizome. J Pharm Res 2018;12:293-7.

13. Rahayu DU, Hartono, Sugita P. Antibacterial activity of curcumenol from rhizomes of Indonesian Curcuma aeruginosa (Zingiberaceae). Rasayan J Chem 2018;11:762-5

14. Sugita P, Firdaus SO, Ilmiawati A, Rahayu DU. Curcumenol: A guaiane-type sesquiterpene from Indonesian Curcuma Heyneana rhizome and it's antibacterial activity towards Staphylococcus aureus and Escherichia coli. J Chem Pharm Res 2018;10:68-75.

15. Purwantiningsih, Hartono, Firdaus SO, Kurniawanti, Rahayu DU, Nurhayati L, et al. Sesquiterpenes from Indonesian of Curcuma aeruginosa rhizome and its antibacterial activities. Drug Invent Today 2019;11:386-90.

16. Rahayu DU, Nurfadhilah D, Sugita P. Phytochemical study of Indonesian Curcuma rotunda rhizome and its antioxidant activity towards 1,1-diphenyl-2-picrylhydrazyl (DPPH). Int J Pharm Sci Res 2019; 10:33548.

17. Purwantiningsih, Jannah N, Rahayu DU. Two flavanones from fingerroot (Curcuma rotunda) and its antibacterial activities. Rasayan J Chem 2020;13:322-6.

18. Jung EB, Trinh TA, Lee TK, Yamabe N, Kang KS, Song JH, et al. Curcuzedoalide contributes to the cytotoxicity of Curcuma zedoaria rhizomes against human gastric cancer AGS cells through induction of apoptosis. J Ethnopharmacol 2018;213:48-55.

19. Lee TK, Lee D, Lee SR, Ko YK, Kang KS, Chung SJ, et al. Sesquiterpenes from Curcuma zedoaria rhizomes and their cytotoxicity against human gastric cancer AGS cells. Bioorg Chem 2019;87:117-122.

20. Saranraj P, Behera SS, Ray RC. Traditional foods from tropical root and tuber crops: Innovations and challenges. In: Galanakis CM, editor. Innovations in Traditional Foods. $1^{\text {st }}$ ed., Ch. 7. Netherlands: Elsevier Inc.; 2019. p. 159-91.

21. Kadam PV, Yadav KN, Bhingare CL, Patil MJ. Standardization and quantification of curcumin from Curcuma longa extract using UV visible spectroscopy and HPLC. J Pharmacogn Phytochem 2018; 7:1913-8.

22. Arrue L, Barra T, Camarada MB, Zarate X, Schott E. Electrochemical and theoretical characterization of the electro-oxidation of dimethoxycurcumin. Chem Phys Lett 2017;677:35-40.

23. Markatou E, Gionis V, Chryssikos GD, Hatziantoniou S, Georgopoulos A, Demetzos C, Molecular interactions between dimethoxycurcumin and Pamam dendrimer carriers. Int $\mathrm{J}$ Pharm 2007;339:231-6.

24. Zhou H, Liu Y, Lv L, Wang W, Hu H, Yang L, et al. Design and evaluation of a solid dispersion and thermosensitive hydrogel combined local delivery system of dimethoxycurcumin. J Drug Deliv Sci Tec 2019;53:101150.

25. Zanetti TA, Biazi BI, Coatti GC, Baranoski A, Marques LA, Corveloni, AC, et al. Mitotic spindle defects and DNA damage induced by dimethoxycurcumin lead to an intrinsic apoptosis pathway in HepG2/C3A cells. Toxicol In Vitro 2019;61:104643.

26. Jayakumar S, Patwardhan RS, Pal D, Sharma D, Sandur SK. Dimethoxycurcumin, a metabolically stable analogue of curcumin enhances the radiosensitivity of cancer cells: Possible involvement of ROS and thioredoxin reductase. Biochem Bioph Res Co 2016;478:446-54.

27. Benediktsdottie BE, Baldursson $\mathrm{O}$, Gudjonsson $\mathrm{T}$, Tonnesen $\mathrm{HH}$, Masson M. Curcumin, bisdemethoxycurcumin and dimethoxycurcumin complexed with cyclodextrins have structure specific effect on the paracellular integrity of lung epithelia in vitro. Biochem Biophys 2015;4:405-10

28. Syu WJ, Shen CC, Don MJ, Ou JC, Lee GH, Sun CM. Cytotoxicity of curcuminoids and some novel compounds from Curcuma zedoaria. J Nat Prod 1998;61:1531-4.

29. Nong HV, Hung LX, Thang PN, Chinh VD, Vu LV, Dung PT, et al. Fabrication and vibration characterization of curcumin extracted from turmeric (Curcuma longa) rhizomes of the Northern Vietnam. Springerplus 2016;5:1147.

30. Kulkarni SJ, Maske KN, Budre MP, Mahajan RP. Extraction and purification of curcuminoids from Turmeric (Curcuma longa L.). Int $\mathrm{J}$ Pharmacol Pharm Tech 2012;1:81-4

31. Liu F, Bai X, Yang FQ, Zhang XJ, Hu Y, Li P, et al. Discriminating from species of Curcumae Radix (Yujin) by a UHPLC/Q-TOFMS-based metabolomics approach. Chin Med 2016;11:1-11.

32. Tsimogiannis D, Samiotaki M, Panayotou G, Oreopoulou V. Characterization of flavonoid subgroups and hydroxy substitution by HPLC-MS/MS. Molecules 2007;12:593-606.

33. Gunasekaran S, Abraham L, Mathuram V. UV-visible spectral investigation of Gardenin-A using shift reagents. Asian J Chem 2005; 17:2040-2

34. Huang L, Feng ZL, Wang YT, Lin LG. Anticancer carbazole alkaloids and coumarins from Clausena plants: A review. Chin J Nat Med 2017;15:881-8.

35. Machynakova A, Hrobonova K. Simultaneous determination of coumarin derivatives in natural samples by ultra-high performance liquid chromatography. J Food Nutr Res 2017;56:179-88.

36. Divakaran SA, Hema PS, Nair MS, Nak CK. Antioxidant capacity and radioprotective properties of the flavonoids galangin and kaempferide isolated from Alpinia galanga L. (Zingiberaceae) against radiation induced cellular DNA damage. Int J Radiat Res 2013;11:81-9.

37. Hamed MM, Mohamed MA, Ibrahim MT. Cytotoxic activity assesment of secondary metabolites from Tecomaria capensis v. aurea. Int J Pharmacogn Phytochem Res 2016;8:1173-82

38. Lefahal M, Zaabat N, Djarri L, Benahmed M, Medjroubi K, Laouer H, et al. Evaluation of the antioxidant activity of extracts and flavonoids obtained from Bunium alpinum Waldst. and Kit. (Apiaceae) and Tamarix gallica L. (Tamaricaceae). Curr Issues Pharm Med Sci 2017;30:5-8.

39. Ahmad A, Misra LN. Isolation of herniarin and other constituents from Matricaria chamomilla flowers. Int J Pharmacogn 1997;35:121-5.

40. Tine Y, Diop A, Diatta W, Desjobert JM, Boye CS, Costa J, et al. Chemical diversity and antimicrobial activity of volatile compounds from Zanthoxylum zanthoxyloides Lam. according to compound classes, plant organs and Senegalese sample locations. Chem Biodivers 2017;14:1-37.

41. Kong LY, Qin MJ, Niwa M. New cytotoxic bis-labdanic diterpenoids from Alpinia calcarata. Planta Med 2002;68:813-7. 